\title{
Factors Contributing to the Fluctuation in Residential Construction in Iran
}

Hassan Gholipour Fereidouni, (Universiti Sains Malaysia, Malaysia)

\section{Abstract}

Residential construction is one of the most important pillars of Iran's economy. Although this sector had an increasing trend over the past two decades, the growth rate of residential construction has been very volatile. The purpose of this paper is to empirically investigate those factors contributing to this fluctuation over the 1991:Q2-2008:Q4. By applying cointegration approach, the empirical results show that housing prices, construction costs, GDP and gold prices are important factors to predict changes in the level of residential construction in Iran.

Keywords: Housing, Construction Costs, Residential Construction, Cointegration Approach, Iran

\section{Introduction}

The last two decades have witnessed a strong growth in construction activity in Iran. The private sector investment in new buildings in urban areas has recorded impressive growth during the 1992-2008 period, with the annual growth rate of 33\% (See Figure 1). Similarly, building activities can also be traced through the number of construction permits issued by municipalities in urban areas. During the period 1991-2008, the average annual construction permits was 140,286 items and reached the highest peak in 2007 (208,922 items). It is a matter of fact that the investment in construction sector has been a major driver of economic growth (Lopes, 1998), by stimulating the demand for many other industries such as electronics, machinery, steel, architecture, and chemical products. A recent statistics provided by Global Market Information Databases (GMID, 2011) indicates that construction and real estate sector contributed about 17 percent of Iranian GDP over the period of 1995-2009.

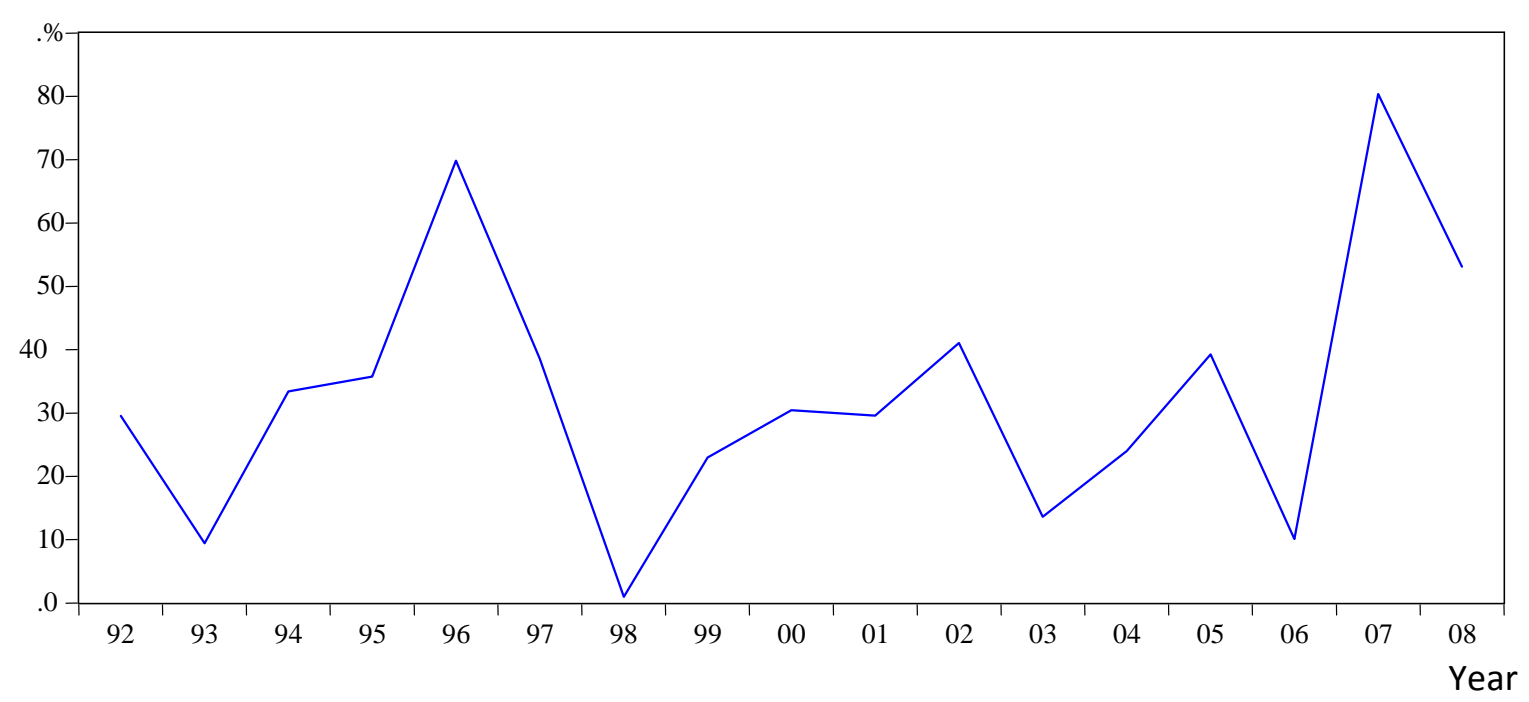

Figure 1 Annual growth rates of private investment in new buildings in urban areas (source: Central bank of Iran) 
One of the important components of the total construction investment in Iran is residential construction. During the period 1992-2007, construction permits for residential building represents around 88 percent of total construction permits (See Figure 2). The share of residential housing sector of total capital formation was around 25-30\% in 2007 (MHUD, 2007). Furthermore, around $25 \%$ of Iran economy's liquidity is allocated to the housing sector and also $14.6 \%$ of the employed male population is active in this sector (Abbasinezhad and Yari, 2009).

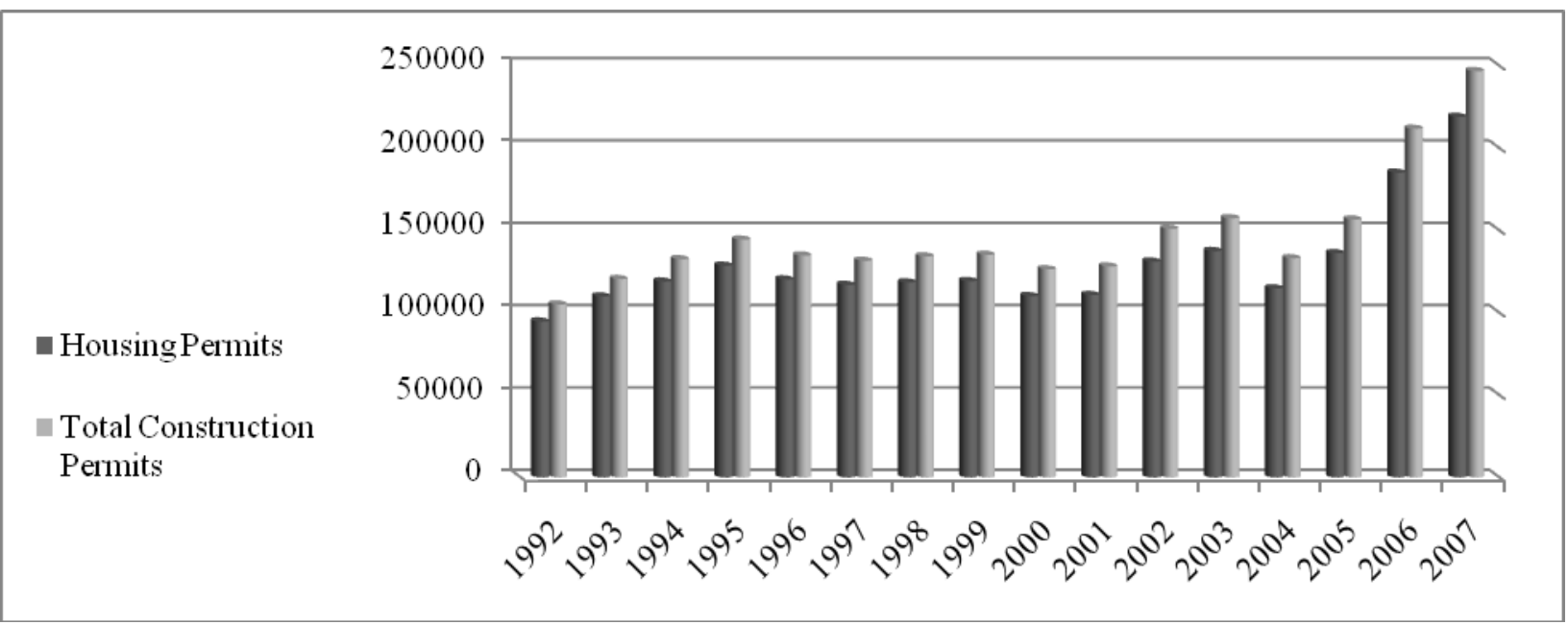

Figure 2 The share of construction permits for residential out of total number of construction permits (Source: Statistical Center of Iran)

However, as can be seen from Figure 1, the growth rate of residential investment was very volatile during the period 1992-2008. In more detail, during this period, the standard deviation of growth rate of residential investment was $20 \%$. Moreover, the highest and lowest growth rate was related to 2007 (80\%) and 1998 (0.9\%) respectively. In this paper we aim to empirically investigate those factors contributing to the fluctuation in residential construction in Iran over the period 1991:Q2-2008:Q4.

This paper contributes to the construction investment literature and provides some implications for policymakers and real estate developers. Firstly, although previous studies have examined the determinants of investment in housing, to the best of our knowledge, there is no recent work on the housing market of Iran. Most studies in this area cover United States (U.S.) and European real estate markets. Findings for developed countries might not be directly transferable to emerging economies such as Iran, therefore, more work is necessary to obtain a clearer picture of residential construction in emerging economies. Secondly, from previous literature it is apparent that relatively few researchers have studied the effects of gold prices on construction investment. We add this variable to our model because (culturally) gold is a valuable asset for Iranian families and whose price changes may influence household's residential construction decisions. In particular, it is a case in small cities. Thirdly, investment in residential dwelling has been one of the main components of Iranian non-oil GDP. Therefore, housing construction can lead recoveries and recessions in the economy of Iran. Finally, changes in new housing supply affect the price of existing housing units, with implications for the wealth position of homeowners and housing affordability (Mayer and Somerville, 2000).

Given the significant role of the housing sector in the economy of Iran, identifying those factors contributing to the swings of residential construction is important to policymakers because

Fereidouni, H G (2011) 'Factors contributing to the fluctuation in residential construction in Iran', Australasian Journal of Construction Economics and Building, 11 (4) 77-86 
fluctuations in residential construction have a large impact on GDP. Furthermore, our results help real estate developers to have a better understanding of the long run determinants of residential construction.

The paper is structured as follows: in the next section are presented some facts regarding the residential construction in Iran. Section 3 reviews the relevant literature. In section 4 the most significant hypothesis about the determinants for residential construction are exposed. Section 5 describes the methodology used in this paper. Section 6 reports the empirical results and section 7 makes some concluding remarks.

\section{Some Facts about Residential Construction in Iran}

This section provides some facts about residential construction in Iran. Housing production has been almost entirely carried out by the private sector in Iran. The state participation in housing market has been less than 10 percent. However, the role of government in the housing market has increased through Mehr Housing Scheme in past three years. Under this scheme real estate developers are offered free lands in return for building cheap residential units for firsttime buyers on 99-year lease contracts.

Only one bank in Iran, Maskan Bank (or Housing Bank) provides loans for building, purchasing and repairing houses. In 2009, the maximum loan offered by this bank was IRR180 million which equals almost 20 percent of the cost of a sixty square meter flat in a major city such as Tehran (GMID, 2011).

Worldwide, Iran is ranked 143 overall for dealing with construction permits and other formal requirements among 183 economies. According to the World Bank's Doing Business report ${ }^{1}$ (2011), it requires 17 procedures, takes 322 days, and costs $382.35 \%$ income per capita to construct a building in Iran. Table 1 shows dealing with construction permits data for Iran compared to good practice and comparator economies.

\begin{tabular}{|l|c|c|c|}
\hline \multicolumn{1}{|c|}{ Indicators } & Iran & $\begin{array}{c}\text { Comparable } \\
\text { Economies (Middle } \\
\text { East \& North Africa) }\end{array}$ & $\begin{array}{c}\text { Good Practice } \\
\text { Economies (OECD) }\end{array}$ \\
\hline Procedures (number) & 17 & 18.7 & 15.8 \\
\hline Time (days) & 322 & 151.9 & 166.3 \\
\hline Cost (\% of income per capita) & 382.3 & 409.7 & 62.1 \\
\hline
\end{tabular}

Table 1 Dealing with construction permits and other formal requirements (Source: The World Bank and the International Finance Corporation)

\section{Literature Review}

A number of researchers have studied the determinants of construction investment. This section of paper intends to survey some of the previous researches which are more relevant to our study.

By applying the vector error correction (VEC) and time series multiple regression models $\mathrm{Ng}$ et al. (2011) forecasted private construction investment in Hong Kong. Their results showed that the real GDP, unemployment and public sector construction output are the factors influencing

\footnotetext{
${ }^{1}$ See http://www.doingbusiness.org/methodology/dealing-with-construction-permits for a complete description of the Dealing with Construction Permits portion of the Doing Business database.
}

Fereidouni, H G (2011) 'Factors contributing to the fluctuation in residential construction in Iran', Australasian Journal of Construction Economics and Building, 11 (4) 77-86 
private construction investment. In his study on determinants of house prices and construction activities in Switzerland, Borowiecki (2009), by applying a VAR model, found that construction activities and house prices are very sensitive to changes in population and construction prices. Al-Abdulrazag (2003) employed a regression approaches to model Jordanian private construction investment. His results indicated that GDP growth, flow of remittances, bank credit, real interest rate and population growth are relevant factors explaining construction sector investment in Jordan. Furthermore, he found that government expenditures have a net positive impact on construction investment.

By using quarterly data over the period 1974 to 1988, Akintoye and Skitmore (1994) analyzed the determinants of private sector construction demand in three sub-sectors (including housing, commercial and industrial construction). Regarding the housing sector, they found that demand is negatively correlated with price level of construction and positively correlated with gross national product (GNP) and real interest rate. Moreover, their time-series regression results showed that there are no significant relationships between unemployment and manufacturing profitability and private sector construction demand in housing. Similarly, Tang et al. (1990) used regression analysis to estimate demand functions for three types of construction (residential, non-residential and public projects). Their empirical results for residential construction indicated that the ratio of consumer price index to the construction cost index, rising per capita income, and population are the main determinants of demand for residential construction.

He et al. (2009) investigated the determinants of foreign direct investment in China's real estate development. Applying a panel data regression model, their statistical results indicated that foreign real estate investors and developers avoid provinces with high labor and financing costs but significantly favor provinces with higher housing prices, developed land and housing commercialization, good governance, strong law enforcement and developed services.

Applying unit root tests and Granger causality tests, Tse and Ganesan (1997) analyzed the causal and short-tem relationship between construction flows and GDP in Hong Kong. Their findings indicated that GDP leads construction flows, and not vice versa. Likewise, Wigren and Wilhelmsson (2007) found that GDP Granger cause total construction in the short run in Western Europe. Yiu et al. (2004) provided evidences that there is a casual linkage between the real growth rate of construction output and the real growth rate of GDP in Hong Kong.

Mayer and Somerville (2000), based on urban growth theory, developed an empirical model of new single-family housing supply. Their empirical estimates showed that housing starts are affected by changes in existing and lagged house prices and costs. By focusing on U.S. housing market, Coulson (1999) examined the sources of fluctuations in housing completions and inventory for the period 1968 through 1995. Coulson found that the housing completion rate is not affected by shocks to income, interest rates, materials price, and housing price and appeared to be more or less constant over the time. In addition, he found that the number of completions depends more on the extent of unfinished inventory and the technology of finishing work. Donatos (1995) examined the effects of income, demographic factors, building costs, finance and saving on investment in housing for the period 1958-1989 in Greece. By applying ordinary least squares (OLS) estimation, he found that income and population influence significantly investment decisions. Moreover, his findings showed that financial variables were not significant determinants of housing investment.

McGarvey and Meador (1991) examined the relationship between housing starts and the availability of mortgage credit in the U.S. Their results indicated that mortgage credit availability

Fereidouni, H G (2011) 'Factors contributing to the fluctuation in residential construction in Iran', Australasian Journal of Construction Economics and Building, 11 (4) 77-86 
contributed significantly to short-run cycles in housing starts. Similarly, by using U.S. monthly data over 1967-1984, Thom (1985) found that housing starts are significantly influenced by both interest rates and mortgage availability. Topel and Rosen (1988) found that housing investment responds elastically to changes in asset prices in the U.S. By using spectral analysis on U.S. data, Tan (1988) found that future expectation, business profits and interest rate influence construction investment decisions.

\section{Factors Contributing to the Fluctuation in Residential Construction in Iran ${ }^{2}$}

In this section we select the variables to test for our empirical analysis. This choice is guided by three considerations: the relevance of the variables in question from the perspective of the Iranian economy, the availability of data and the need for a parsimonious specification imposed by the relatively small size of the sample. The following variables were chosen for econometric investigation: dependent variable is Residential Construction and explanatory variables are Construction Costs, Housing Prices, GDP, Credit to Construction and Housing Sector and Gold Prices. The remaining part of this section will discuss this selection.

\section{Dependent Variable}

In order to measure residential construction, we use construction permits issued by municipalities in urban areas. During the period 1991-2008, the average annual construction permits was 140,286 items and reached a peak in 2007 with 208,922 items. However, as mentioned earlier, the number of construction permits had high fluctuation during the 1992-2008 period, with the maximum and minimum annual growth rate of $0.28(28 \%)$ and $-0.16(-16 \%)$ respectively (See Figure 3). The data for this variable is obtained from Central Bank of Iran.

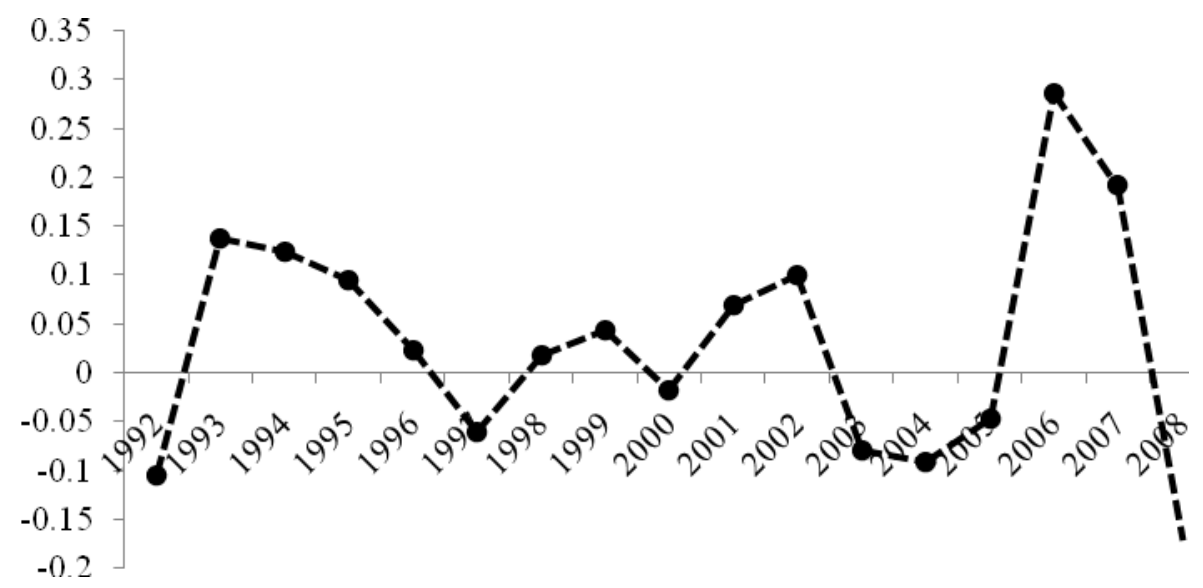

Figure 3 Annual growth rates of construction permits in urban areas (Source: Central Bank of Iran)

\section{Explanatory Variables}

Construction Costs: The first hypothesis to be tested is the relationship between residential construction and construction costs. It is expected that the construction costs variable has a negative and long-run relation with residential construction. This is motivated by the findings of Borowiecki (2009) and Akintoye and Skitmore (1994) who showed that construction price appeared to be an important influence in housing investment. We employ construction service index provided by Central Bank of Iran to measure construction costs.

\footnotetext{
${ }^{2}$ It should be noted that the interest rate was dropped from our empirical model because interest rate for construction and housing loans was almost constant over the period of this study.
}

Fereidouni, H G (2011) 'Factors contributing to the fluctuation in residential construction in Iran', Australasian Journal of Construction Economics and Building, 11 (4) 77-86 
Housing Prices: Previous studies and economic theory suggest that an increase in house prices leads to a rise in the housing construction. For example, Baffoe-Bonnie (1998) argues that the depression of real housing prices would retard new investment in housing, and the volume of new housing starts would fall. Similarly, He et al. (2010) found that heightening housing prices significantly stimulated the inflow of foreign investment in China' real estate development. So we hypothesize a positive relationship between housing prices and residential construction. Since the data for housing price is not available for the period of the study the rental value index - which has a very high correlation with housing prices in recent years $(r=$ 0.98) - was used as a proxy for housing prices. This data is obtained from Central Bank of Iran.

Gross Domestic Products (GDP): A positive relationship has generally been found between GDP and investment in residential construction (e.g., $\mathrm{Ng}$ et al., 2011; Tse and Ganesan, 1997). In other words, it is argued that construction investments occur more during an economic boom. It is because higher GDP would create more demand for real estate properties, therefore attracting more investment into the real estate industry. Given past empirical research on the effects of GDP on construction investment, a positive coefficient is expected for the GDP variable in the present study. This data is obtained from Central Bank of Iran.

Credit to Construction and Housing Sector: Another hypothesis to be tested is the relationship between credit to construction and housing sector and residential construction. It is expected that swings in credit to construction and housing sector has a direct effect on fluctuation in residential construction. It is because higher value of banking loans to construction and housing sector can lower financing costs for investment (He et al., 2010). According to statistics provided by the Central Bank of Iran, outstanding facilities by banks and credit institutions to construction and housing sector accounted, on average, for around $32 \%$ of total credit to the non-public sectors over the period 1979 to 2008 . Due to unavailability of quarterly data for this variable, quarterly data on claims on the private sector ${ }^{3}$, provided by IMF, were used. This figure was divided by three to obtain an approximation to the credit to construction and housing.

Gold Prices: Gold has traditionally been important in Iran for cultural reasons. It is common for Iranian families to allocate a (considerable) proportion of their assets to various forms of gold (such as gold coins, gold necklaces etc.). Residential construction is expected to have either a negative or a positive relationship with gold prices. Some observers argue that when returns from the gold market fall, there are more incentives for households and investors to invest in the housing sector (e.g. Iran Economics, 2004; Masron and Gholipour, 2010). On the other hands, some believe that when returns from the gold market rise, the wealth effect encourages some households to start building new houses, particularly in small cities The Gold Coin Price, used to measure this variable, is provided by the Central Bank of Iran.

In summary, the model for residential construction in Iran can be expressed as:

$\operatorname{InPERMIT}_{t} \mathrm{C}+\beta 1 \operatorname{InCCOST}_{t}+\beta 2 \operatorname{lnRENT} T_{t}+\beta 3 \operatorname{InGDP}_{t}+\beta 4 \operatorname{lnCCH}_{t}+\beta 5 \operatorname{lnGOLD}{ }_{t}+U_{t}$

where PERMIT is the construction permits issued by municipalities in urban areas; CCOST is construction costs; RENT is the rental index, proxy for housing prices; GDP is the gross domestic product; $\mathrm{CCH}$ is the credit to construction and housing sector; GOLD is the gold coin

\footnotetext{
${ }^{3}$ According to IMF, claims on private sector include gross credit from the financial system to individuals, enterprises, nonfinancial public entities not included under net domestic credit, and financial institutions not included elsewhere.
}

Fereidouni, H G (2011) 'Factors contributing to the fluctuation in residential construction in Iran', Australasian Journal of Construction Economics and Building, 11 (4) 77-86 
price and $U$ is an error term. It should be noted that the logarithm for the dependent and the independent variables is used. Time series data is used to run the model put forward in equation (1). The time span we used is the period 1991: quarter 2 - 2008: quarter 4. Description and sources of variables can be found in Table 2 .

\begin{tabular}{|c|l|l|l|}
\hline Variables & \multicolumn{1}{|c|}{ Description } & \multicolumn{1}{c|}{$\begin{array}{c}\text { Proxy for/ Actual } \\
\text { Measure }\end{array}$} & \multicolumn{1}{c|}{ Sources } \\
\hline PERMIT & $\begin{array}{l}\text { Construction permits issued by } \\
\text { municipalities in urban areas }\end{array}$ & $\begin{array}{l}\text { Proxy for residential } \\
\text { construction investment }\end{array}$ & Central Bank of Iran \\
\hline CCOST & Construction cost index & Actual measure & Central Bank of Iran \\
\hline RENT & Rental index & Proxy for housing prices & Central Bank of Iran \\
\hline GDP & Gross domestic product & Actual measure & Central Bank of Iran \\
\hline CCH & Claims on private sector & $\begin{array}{l}\text { Proxy for credit to } \\
\text { construction and housing }\end{array}$ & $\begin{array}{l}\text { International Monetary } \\
\text { Fund }\end{array}$ \\
\hline GOLD & Gold price & Actual measure & Central Bank of Iran \\
\hline
\end{tabular}

Table 2 Variables, Description and Sources

\section{Method}

This section presents the method used in this paper for the treatment of time series data. In order to avoid spurious results when data are non-stationary, cointegration is the most widely used technique. Given the attractiveness of cointegration technique to model the long run relationships among variables (Cr^otte et al. 2010; Brissimis and Vlassopoulos, 2009), we apply this method to estimate the long run relationships among explanatory variables (construction costs, housing prices, GDP, credit to construction and housing sector and gold prices) and residential construction.

As a preliminary step, standard unit root tests Augmented Dickey-Fuller (ADF) tests, (Dickey and Fuller 1981) are applied to the variables included in the model to determine whether they are stationary or not. Second, the long run elasticities are estimated through a cointegrating regression if the residuals are stationary. In other words, we estimate the cointegrating equation, and the obtained parameters can be considered the best method to measure long-run relationships. Then, the residuals from the equation must be examined to determine if they are stationary variables. If so, the model can be used to infer conclusions about the long run relationships among the variables (Rodríguez and Bustillo, 2010).

Given the difficulties with obtaining the long run parameters through a cointegrating regression based on a traditional ordinary least square (OLS) static ${ }^{4}$ model, we used the fully modified OLS (FMOLS) estimator that "applies semi-parametric adjustments to the OLS estimator to correct for possible endogeneity and serial correlation in the errors" (Cr^otte et al. 2010, pp. 4452). Finally, the stability of the parameters were tested by Hansen's Instability test. Hansen (1992) outlines a test of the null hypothesis of cointegration against the alternative of no cointegration.

\section{Results}

This section presents the results of the time series cointegration approach. First, the stationarity of the logarithmic form of each series was tested with the ADF unit root test. The results suggest

\footnotetext{
${ }^{4}$ Possible dynamics are not considered in OLS model (Maddala and Kim, 2004).

Fereidouni, H G (2011) 'Factors contributing to the fluctuation in residential construction in Iran', Australasian Journal of Construction Economics and Building, 11 (4) 77-86
} 
that all variables are integrated of order one, i.e. that the variables were transformed into stationarity by differencing once.

\begin{tabular}{|c|c|c|}
\hline Variables & Levels & 1st differences \\
\hline InPERMIT & $-2.71^{* *}$ & $-2.99^{\star *}$ \\
\hline InCCOST & -0.39 & $-3.35^{\star *}$ \\
\hline InRENT & -1.09 & $-2.64^{* *}$ \\
\hline InGDP & 3.37 & $-4.09^{\star * *}$ \\
\hline InCCH & -0.01 & $-2.82^{\star *}$ \\
\hline InGOLD & -1.41 & $-3.37^{\star * *}$ \\
\hline
\end{tabular}

Table 3 ADF t-test for stationarity

Note: ${ }^{* * *},{ }^{* *}$, and ${ }^{*}$ denote significance at the $1 \%, 5 \%$, and $10 \%$ levels, respectively

The residual unit root tests indicate that there is conintegration because the residuals are stationary. The long run coefficients (estimated by FMOLS) are reported in Table 4. Construction cost is negatively related to residential construction (PERMIT). It means that higher construction costs reduce residential construction in Iran. This result is in agreement with Borowiecki (2009) and Mayer and Somerville (2000). The estimated housing prices (proxied by rental index) coefficient carries the expected positive sign. This result suggests that increasing house prices (RENT) stimulate residential construction. This is consistent with Baffoe-Bonnie (1998) and Mayer and Somerville (2000). Furthermore, the analysis finds that GDP has a positive and statistically significant (at the 1 percent level) effect on residential construction, concurring with other similar studies ( $\mathrm{Ng}$ et al., 2011; Tse and Ganesan, 1997). The results also indicate that there is not a significant and long run relationship between credit to construction and housing sector $(\mathrm{CCH})$ and PERMIT. This finding is consistent with Donatos (1995) who argues that financial variables are not the significant determinants of housing investment. It should be noted that $\mathrm{CCH}$ (lagged one period) had a positive and significant relationship between with PERMIT. Finally, the GOLD parameter is statistically significant and positive, suggesting that an increase in contemporaneous gold prices exerts a direct effect on PERMIT. This is consistent with previous studies that argue that heightening gold prices can increase housing investment through wealth effect.

\begin{tabular}{|c|c|}
\hline \multicolumn{2}{|c|}{ Dependent Variable: InPERMIT } \\
\hline Explanatory Variables & Coefficient \\
\hline CCOST & $-0.90(-4.77)^{\star \star \star}$ \\
\hline RENT & $0.68(3.40)^{\star * \star}$ \\
\hline GDP & $0.46(4.30)^{\star \star \star}$ \\
\hline CCH & $0.49(1.06)$ \\
\hline GOLD & $1.13(4.59)^{\star \star \star}$ \\
\hline Adjusted R-squared & 0.33 \\
\hline N & 70 \\
\hline DW & 1.73 \\
\hline
\end{tabular}

Table 4 Cointegrating Regression (FMOLS Method)

Note: ${ }^{* * *},{ }^{* *}$, and ${ }^{*}$ denote significance at the $1 \%, 5 \%$, and $10 \%$ levels, respectively. $t$-statistics are reported in brackets.

Fereidouni, H G (2011) 'Factors contributing to the fluctuation in residential construction in Iran', Australasian Journal of Construction Economics and Building, 11 (4) 77-86 
The stability of the parameters was tested by using Hansen's Instability test. The $L_{c}$ test statistic value of 0.654 indicates that the series are cointegrated at conventional levels i.e. the parameters are stable.

\section{Conclusion}

Over the last two decades, residential construction has been one of the most important pillars of economy of Iran. However, residential construction is ranked among the most volatile industries. The purpose of this study has been to investigate the factors contributing to the fluctuation in residential construction in Iran over the period 1991:Q2-2008:Q4. The empirical results show that construction costs, GDP, housing prices and gold prices are all relevant factors explaining fluctuation in residential construction. Furthermore, one-period lagged credit to the construction and housing sector is a significant determinant of residential construction.

Ultimately, the results of the study should be considered in light of its limitations. Given the data constraints, results should be viewed with caution and data from a longer period is needed to fully investigate the relationships between explanatory variables and residential construction. Furthermore, we could not include some important explanatory variables (e.g., infrastructure development and public savings) due to difficulty to obtain quarterly data for them.

\section{Acknowledgement}

The author would like to thank the Institute of Postgraduate Studies (IPS), Universiti Sains Malaysia (USM) for providing a fellowship to support this research.

\section{References}

Abbasinezhad, H. and Yari, H. (2009) 'The effect of oil shocks on housing prices', Fas/namheye pazhoheshhaye eghtesadi [Quarterly Economic Research], 1, Spring, 59-77

Al-Abdulrazag, B.A. (2003) 'The determinants of private construction investment in Jordan: an empirical study (1972-1996)', Damascus University Journal, 19, 15-35

Akintoye, A. and Skitmore, M. (1994) 'Models of UK private sector quarterly construction demand', Construction Management and Economics, 12 (1), 3-13

Brissimis, S. N. and Vlassopoulos, T. (2009) 'The interaction between mortgage financing and housing prices in Greece', The Journal of Real Estate Finance and Economics, 39 (2), 146-164

Borowiecki, K. J. (2009) 'The determinants of house prices and construction: an empirical investigation of the Swiss housing economy', International Real Estate Review, 12 (3), 193-220

Coulson, E. (1999) 'Housing inventory and completion', Journal of Real Estate Finance and Economics, 18 (1), 89-106

Cr^otte, A., Noland, R. B. and Graham, D. J. (2010) 'An analysis of gasoline demand elasticities at the national and local levels in Mexico', Energy Policy, 38 (8), 4445-4456

Dickey, D. and Fuller, W. (1981) 'Likelihood ratio statistics for autoregressive time series with a unit root', Econometrica, 49 (4), 1057-1072

Donatos, G. (1995) 'A quantitative analysis of investment in new housing in Greece', Urban Studies, 32 (9), 1475-1487

GMID (2011) Global Market Information Databases. available at: http://www.portal.euromonitor.com/Portal/Pages/Magazine/WelcomePage.aspx

He, C., Wang, J. and Cheng, S. (2009) 'What attracts foreign direct investment in China's real estate development?', The Annals of Regional Science, 46 (2), 267-293

Fereidouni, H G (2011) 'Factors contributing to the fluctuation in residential construction in Iran', Australasian Journal of Construction Economics and Building, 11 (4) 77-86 
Iran Economics (2004) 'Chehreh bazar maskan Iran', Mahnameh Eghtesade Iran [Monthly Economy of Iran], 64, available at http://www.iraneconomics.net/fa/printarticle.asp?id=212

Lopez, J (1998) 'The construction industry and macroeconomy in Sub-Saharan Africa post 1970', Construction Management and Economics, 16 (6), 637-649

Maddala, G.S. and Kim, I. (1998) Unit Roots, Cointegration, and Structural Change, Cambridge University Press, Cambridge

Masron, T. A. and Gholipour, H. F. (2010) 'Performance and Diversification Benefits of Housing Investment in Iran', International Journal of Economics and Finance, 2 (4), 7-11

Mayer, C. J. and Somerville, C. T. (2000) 'Residential construction: using the urban growth model to estimate housing supply', Journal of Urban Economics 48, 85-109

McGarvey, M., and Meador, M. (1991) 'Mortgage credit availability, housing starts and the integration of mortgage and capital markets: new evidence using linear feedback', Journal of the American Real Estate and Urban Economics Association, 19, 25-40

MHUD (2007) Foreign investment in the housing sector of Iran, Ministry of Housing \& Urban Development of Iran

Ng, S.T., Fan, R.Y.C. and Wong, J. M. W. (2011) 'An econometric model for forecasting private construction investment in Hong Kong', Construction Management and Economics, 29 (5), 519534

Rodriguez. C. and Bustillo, R. (2010) 'Modeling foreign real estate investment: The Spanish case', Journal of Real Estate Finance and Economics, 41 (3), 354-367

Tan, W. (1988) 'GNP, interest rate and construction investment: empirical evidence from US data', Construction Management and Economics, 6 (3), 185-193

Tang, J.C.S., Karasudhi, P. and Tachopiyagoon, P. (1990) 'Thai construction industry: demand and projection', Construction Management and Economics, 8 (3), 249-257

Thom, R. (1985) 'The relationship between housing starts and mortgage availability', The Review of Economics and Statistics, 67 (4), 693-696

Topel, R. and Rosen, S. (1988) 'Housing investment in the United States', The Journal of Political Economy, 96 (4), 718-740

Tse, R. Y. C. and Ganesan, S. (1997) 'Causal relationship between construction flows and GDP: evidence from Hong Kong', Construction Management and Economics 15 (4), 371-376

Wigren, R. and Wilhelmsson, M. (2007) 'Construction investments and economic growth in Western Europe', Journal of Policy Modeling, 29 (3), 439-451

Yiu, C.Y., Lu, X.H., Leung, M.Y. and Jin, W.X. (2004) 'A longitudinal analysis on the relationship between construction output and GDP in Hong Kong', Construction Management and Economics, 22 (4), 339-45 